\title{
TPACK Capability Preservice Teachers Civic Education in the Era of Industrial Revolution 4.0
}

\author{
Aulia Nursyifa1', Imam Fitri Rahmadi, Eti Hayati \\ Department of Civic education, Pamulang University \\ e-mail: aulianursyifa@unpam.ac.id, imamrahmadi@unpam.ac.id, etihayati@yahoo.co.id
}

\begin{abstract}
This research aimed at determining the ability of the Technological Pedagogical Content Knowledge (TPACK) of preservice teachers in Civic Education Pamulang University. The method used in this research is a quantitative method with survey approach. The research subjects were 63 students. The results showed that the ability of TPACK has a very important role in improving the ability of preservice teachers in the 4.0 industrial revolution. Besides the analysis results showed the ability of TPACK Preservice teachers Civic education on group $A$ superior to the group $B$. Therefore, TPACK's capabilities need to be upgraded and supported by various parties to create an education that can produce future qualified teachers.
\end{abstract}

Keywords: Ability; TPACK; Preservice Teachers; Civic Education

\section{Introduction}

The rapid development of technology in various fields of education demanded that the world of education to transform make adjustments in the face of the era Revolution Industry 4.0. History. The first industrial revolution of 1760 at the time of the railway, the Second Industrial Revolution was found electricity, the third Industrial Revolution of the year 1960 found the computer, and the Industrial Revolution of four In the 21st century characterized by the presence of the Internet, computerized data, robotization (Schwab, 2016). Therefore, the era of the 4.0 industrial Revolution is characterized by a digitizing era where humans have been familiar with the technology. The existence of technology as a tool that facilitates the learning process, so that students can easily digest and understand the lessons (Muhson, 2010).

Nowadays, learners are a living generation in the era of technological sophistication so that teachers are not the only source of learning, through the ease that technology makes students very easy to access various sources Literature in learning. Therefore, to answer the current challenges, teachers must have the knowledge and skills to use good learning technology (Drew, 2013; Trust, 2018; Kereluik, Mishra, Fahnoe, \& Terry, 2013). Professional teachers can answer the challenge of the age by adjusting in the teaching, therefore the teacher is compulsory for technological literacy and can use it well in the process of teaching activities. Currently, we are familiar with the terms of use of technology in learning, such as using computers, smartphones, tablets, laptops, printers, projectors, and so on. As well as software, for example: Microsoft PowerPoint, Microsoft Word, Microsoft Excel, video, Internet learning usages such as E-learning, websites, application usage Kahoot, Zoom, Facebook, Youtube, Twitter, Whatsapp, and other technologies available to teachers and students in learning.

The development of technology makes teachers and students have no restrictions on learning anywhere, anytime, and from any source of literation. Preservice teachers are obliged to have a variety of knowledge about technology, has the capability of technology, have skills in using technology, and various competencies regarding technology that teachers can use in teaching, so teachers can integrate various technologies to produce

\footnotetext{
${ }^{1}$ Corresponding author.

Received 28 June 2019; Accepted 24 April 2020; Available online 31 March 2020 (C) 2020 JPI. All Rights Reserved
} 
effective and efficient learning (Koehler and Mishra, 2005; Koehler, et al, 2011; Guzman, 2009).

Knowledge of Preservice teachers in the use of technology is still low (Sholihah, Yuliati, \& Wartono, 2016). Preservice teachers are only limited to the use of certain technologies in teaching and lack of literacy on how to use technology in teaching. On the one hand, the education institution as an institution that produces preservice teachers has not been able to present technological literacy for the teacher Preservice. Education institutions still use the old theory of subject specific pedagogy (Director general of Learning and students, 2018). The theory is similar to pedagogical content knowledge (PCK). Therefore, technological literacy skills must be preservice teachers, so they can integrate knowledge about the use of technology that will be implemented in good teaching. It needs to be revitalized to print qualified teachers in the future who can adapt to technological advancement. One of the knowledge related to technology in education is called TPACK. TPACK is a framework for thinking about teacher knowledge in integrating the ability to use technology with a variety of pedagogical components so that the learning process goes well (Mishra \& Koehler, 2006; Mishra \& Koehler, 2008). TPACK is offered because the knowledge owned by prospective teachers must be comprehensive to use appropriate technology in teaching, tailored to the content of the material being taught, and aspects of pedagogy. TPACK's capabilities can prepare prospective teachers to become professional educators. One of the knowledge related to technology in education is called TPACK. TPACK is a framework to think about the knowledge of teachers in integrating the ability to use technology with various pedagogic components so that the learning process goes well (Mishra \& Koehler, 2006; Mishra \& Koehler, 2008). TPACK is offered because the knowledge possessed by prospective teachers need to be comprehensive to use appropriate technology in teaching, tailored to the content of the material being taught, and aspects of pedagogy. TPACK capability can prepare prospective teachers to become professional educators.

TPACK is divided into several important knowledge components that teachers must have, TK, CK, PK, PCK, TCK, TPK, and TPACK (in Mishra and Koehler, 2006). The following will be described as important components in sharpening the ability of TPACK preservice teachers:

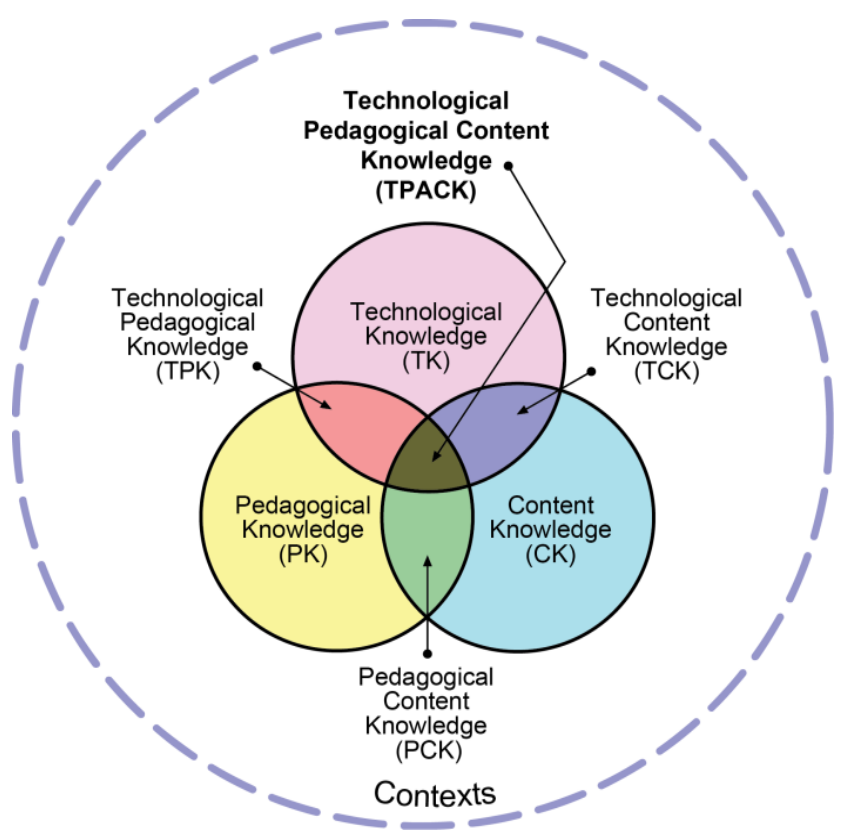

Figure 1. TPACK Components (Mishra and Koehler, 2008)

Based on image 1, TPACK component that interconnectedness of each other between TK, CK, PK, PCK, TCK, TPK, and TPACK. The ability of TPACK teachers can be 
correlated to their way of teaching in the classroom. With the TPACK framework, teachers can explore learning according to the objectives achieved.

TPACK gives the view that technology plays an important role in learning. Various research results about TPACK have been conducted to examine the extent to which the role of TPACK in increasing the competency of teachers in various fields of science. TPACK analysis has been examined by Raman (2014) The results of research conducted by teachers in information technology, have a high level of competence on TPACK capability. Research conducted by Baser, Kopcha, \& Ozden (2015) for Preservice English teachers who have improved knowledge of Preservice teachers in pedagogical abilities and TPACK technological content. Research was also conducted by Cuhadar (2018) about the effectiveness of the use of TPACK technology for Preservice teachers (majors in IPS, English, Mathematics, educational psychology). The results of the research conducted by Jang \& Tsai (2012) to improve the ability of Preservice mathematics teachers in the use of TPACK, in accordance with the study on the use of TPACK in Preservice science teachers (Maeng, Mulvey, Smetana, \& Bell, 2013; Bilici, Guzey, \& Yamak, 2016; Canbazoglu Bilici, Guzey, \& Yamak, 2016).

The research on TPACK also develops in Indonesia, researchers tried to adopt the TPACK toeri in view of preservice teacher skills in the use of learning technology. The results concluded that there was an increase in the ability of TPACK in physics teachers ; Sholihah, 2016; Sholihah, Yuliati, \& Wartono, 2016). TPACK research has been conducted on biology subjects which are research results of TPACK in good category (Agustina, Yusron, \& Muyassarah, 2018; Dhawati, 2017; Fatonah, 2017; Lestari, 2015; Sukaesih, Ridlo, \& Saptono,2017). The ability of TPACK at Science preservice teachers (Rahayu, 2017); Math preservice teachers (Listiawan \& Baskoro, 2015); Preservice teachers in a technical field (Arbiyanto, Widiyanti, \& Nurhadi, 2018).

Based on the results of the relevant research, it can be concluded that TPACK is very beneficial for the Preservice teacher. If viewed from TPACK research that has been done, then no one discussed specifically about the research TPACK in the field of citizenship education. Therefore, the focus of this research seeks to know the ability of TPACK in the preservice teacher of citizenship education, Faculty of teacher training and educational Science University Pamulang. Competence Preservice Teacher is very diverse in the mastery of TPACK, therefore the direction of this research seeks to compare the ability of TPACK preservice teacher among students who lecture group A with group $B$.

TPACK Research is intended for students who are taking field experience practice as preservice teachers for Civic education, Faculty of Teacher Training and Education, Pamulang University. In this research TPACK analysis is only done to compare group classes $A$ with group $B$. By comparing group class, $A$ with the $B$, it is expected to produce interesting research findings to evaluate the implementation of Courses in a variety of morning or evening options. This research aims to know the mastery of the ability of TPACK for teachers of Civic education who are studying in the program of Civic Education, Faculty of Teacher Training and Education, Pamulang University between group A with group B.

\section{Method}

The methods in this study use quantitative methods with a research approach through the survey methods. The survey method was chosen in this study because it made it easier for researchers to analyze the results of research data, the method of self report-measure survey was most selected by various research on TPACK (Mouza, 2016). The method of surveying is also appropriately used on the grounds very well by the context of research researchers because the number of respondents that researchers took in this TPACK study.

This research was conducted in the study program at Civic education, Pamulang University which is located at Jalan Puspitek No. 46 Buaran Serpong Tangerang Selatan. The subject of research in this study is preservice teachers Civic education field experience practice students school year 2017/2018 study program Civic education, Pamulang University group classes $A$ and $B$, which amounted to 63 people. Field experience Practices 
implementation is conducted for 3 months from January to March 2018 in a middle school located in South Tangerang City area.

Research began by collecting questionnaires from previous research that fit the research topic. Questionnaire guidance was seen from the research carried out by Schmidt (2009) and Sahin (2011), a question amounting to 57 questions consisting of 16 TK, 7 CK, 8 PK, 7 PCK, 7 TCK, 7 TPK, and 5 TPACK. Questionnaires created using Likert scales consist of; 1 strongly disagree; 2 Disagree; 3 hesitant; 4 agree; and 5 very agreed. The next step is to pilot the questionnaire to see the validity and reliability of the questionnaire. All instrument items in the questionnaire have been tested for validity using the Pearson product moment correlation. While reliability is tested using Cronbach Alpha with the results TK 0884, CK 0703, PK 0770, PCK 0827, TCK 0858, TPK 0802 and TPACK 0804). After the validity and reliability test, the questionnaire was distributed to preservice students of Field experience practices study program of group classes A and B online through Google Form application. The next steps of data are analyzed in a descriptive statistic with the rating scale and predicate as follows; $1.00-1.50$ (very less); $1.51-2.50$ (less); $2.51-3.50$ (sufficient); 3.5 4.50 (good); and $4.51-5.00$ (very good).

\section{Results}

This research seeks to know the mastery of the ability of TPACK for teachers of civic education who are studying in the program of Civic education, Faculty of Teacher Training and Education, Pamulang University between group program A with group B. After the various series of studies Then obtained the research data that will be a description of the results as follows:

Related to the research results that can be seen from several indicators to know the mastery of TPACK for preservice teachers civic education. Mastery Technological Knowledge (TK) preservice teachers civic education group class A with group B in the table as follows.

Table 1 Capabilities of Technological Knowledge (TK)

\begin{tabular}{|c|c|c|c|c|c|}
\hline No. & Statement & $\mathbf{A}$ & Description & $\mathbf{B}$ & Description \\
\hline 1 & $\begin{array}{l}\text { I know how to solve a technical problem that } \\
\text { occurs on my own computer/laptop. }\end{array}$ & .3 .77 & Good & .3 .57 & Good \\
\hline 2 & I can learn various technologies. & 3.77 & Good & 3.57 & Good \\
\hline 3 & $\begin{array}{l}\text { I followed the development of new technologies } \\
\text { that are important to me. }\end{array}$ & 4.07 & Good & 3.80 & Good \\
\hline 4 & $\begin{array}{l}\text { I often tweaked the technology device to find out } \\
\text { more. }\end{array}$ & 3.87 & Good & 3.37 & Enough \\
\hline 5 & $\begin{array}{l}\text { I know different types of computer } \\
\text { technology/laptops }\end{array}$ & 3.57 & Good & 3.17 & Enough \\
\hline 6 & $\begin{array}{l}\text { I know a variety of computer hardware/laptops } \\
\text { (e.g. motherboard, RAM) and its functions. }\end{array}$ & 3.63 & Good & 3.13 & Enough \\
\hline 7 & $\begin{array}{l}\text { I know a variety of computer/laptop software } \\
\text { (example: Windows, Media Player) and its } \\
\text { functions. }\end{array}$ & 3.87 & Good & 3.43 & Enough \\
\hline 8 & $\begin{array}{l}\text { I know how to use a word processing program } \\
\text { (example: Microsoft Word). }\end{array}$ & 4.27 & Good & 3.97 & Good \\
\hline 9 & $\begin{array}{l}\text { I know how to use the Program processing } \\
\text { columns (example: Microsoft Excel). }\end{array}$ & 4.03 & Good & 3.67 & Good \\
\hline 10 & $\begin{array}{l}\text { I know how to use presentation rendering } \\
\text { program (example: Microsoft Powerpoint). }\end{array}$ & 4.27 & Good & 4.07 & Good \\
\hline 11 & $\begin{array}{l}\text { I know how to use the image processing } \\
\text { program (example: Adobe Photoshop). }\end{array}$ & 3.53 & Good & 3.27 & Enough \\
\hline 12 & $\begin{array}{l}\text { I know how to use a communication application } \\
\text { on the Internet (example: Email). }\end{array}$ & 4.37 & Good & 4.17 & Good \\
\hline 13 & $\begin{array}{l}\text { I know how to use social media applications on } \\
\text { the Internet (example: Facebook, Instagram). }\end{array}$ & 4.57 & Very good & 4.23 & Good \\
\hline
\end{tabular}




\begin{tabular}{clcccc}
\hline No. & \multicolumn{1}{c}{ Statement } & A & Description & B & Description \\
\hline 14 & $\begin{array}{l}\text { I can store data in digital form (example: CD, } \\
\text { DVD, Flash Disk). }\end{array}$ & 4.30 & Good & 4.07 & Good \\
15 & $\begin{array}{l}\text { I can save and change the data in various } \\
\text { formats (example: Convert Ms. Word file to } \\
\text { PDF). }\end{array}$ & 4.27 & Good & 3.77 & Good \\
\hline 16 & $\begin{array}{l}\text { I can use printers, projectors, skaners, and } \\
\text { digital cameras. }\end{array}$ & 4.13 & Good & 3.83 & Good \\
\hline Total & $\mathbf{4 . 0 2}$ & Good & $\mathbf{3 . 6 9}$ & Good \\
\hline
\end{tabular}

Table 1 shows data on the average value of the Technological Knowledge (TK) teachers of civic education in group lecture programs A and group B. The average Total value of primary Technological Knowledge (TK) teachers of civic education in group lecture programs $A$ get score higher than group $B$. Not all items of statements both on group $A$ and $B$ get $A$ good predicate. Knowledge of the use of social media applications on the Internet such as Facebook and Instagram got a very good predicate on the group A with a value of 4.57, the value is 0.34 higher than the group value $B$ at the same grain. In contrast, knowledge about the use of computer hardware or laptops such as motherboards and RAM, only got enough predicate on group B with a value below 3.20 then that value is the lowest value on group $B$. Although Thus, there is a significant difference in value between group $A$ and group $B$ on the ability to save and change data in various formats e.g. modifying MS files. Word to PDF that both have a difference in value 0.50 . In other statement items, there is no significant difference in value and no equal value.

As for other capabilities in this study, which is related to the ability of Content Knowledge (CK), the following will be explained in table 2 about the results of CK preservice teachers Civic education group class A with group B.

Table 2. Content Knowledge (CK) capabilities

\begin{tabular}{clcccc}
\hline No. & \multicolumn{1}{c}{ Statement } & A & Description & B & Description \\
\hline 1 & $\begin{array}{l}\text { I have a good knowledge of the educational } \\
\text { material of Pancasila and Citizenship (Civic }\end{array}$ & .3 .97 & Good & 3.73 & Good \\
$2 \begin{array}{l}\text { education). } \\
\text { I have a variety of strategies to develop the } \\
\text { understanding of the material Civic }\end{array}$ & 3.97 & Good & 3.87 & Good \\
$\begin{array}{l}\text { education. } \\
\text { I can use social science thinking. }\end{array}$ & 4.13 & Good & 3.93 & Good \\
\hline $\begin{array}{l}\text { I follow the development of science and the } \\
\text { latest issues in the field of Civic education. } \\
\text { I know the figure of Civic education scientists } \\
\text { in Indonesia. }\end{array}$ & 3.90 & Good & 3.80 & Good \\
\hline $\begin{array}{l}\text { I follow the development of the latest book } \\
\text { on Civic education. }\end{array}$ & 3.87 & Good & 3.50 & Enough \\
\hline $\begin{array}{l}\text { I participated in a seminar or similar event } \\
\text { that was themed Civic education. }\end{array}$ & 4.07 & Good & 3.87 & Good \\
\hline Total & $\mathbf{3 . 9 2}$ & Good & $\mathbf{3 . 7 4}$ & Good \\
\hline
\end{tabular}

Based on table 2. Shows data about the average value of the civic education of CK teachers in group coursework programs group A and B. The total average score of CK preservice teachers Civic education teachers in group lecture program $A$ higher than in group lecture program B. Not all items of statements both on group $A$ and $B$ get $A$ good predicate. Knowledge on how to think social sciences got a good predicate at group $A$ with a value of 4.13 then the value is 0.20 higher than the group tilapia $B$ in the same grain. However, there is a significant difference in value between group $A$ and group $B$ in following the latest book developments on Civic education material has a value difference of more than 0.30 . In contrast, the knowledge related to the figure of the scientist of Civic education in Indonesia 
on group B has a value of 3.47 hence the value is the lowest value of the group $B$. In other statements, there is no significant difference in value.

The next ability of a very important ability to become a teacher, the ability of Pedagogical Knowledge (PK), table 3 shows the results of the ability Pedagogical Knowledge (PK) preservice teachers Civic education group class $A$ with group $B$.

Table 3 Ability Pedagogical Knowledge (PK)

\begin{tabular}{clcccc}
\hline No. & \multicolumn{1}{c}{ Statement } & A & Description & B & Description \\
\hline 1 & I know how to plan to learn in class. & 4.13 & Good & 4.07 & Good \\
2 & $\begin{array}{l}\text { I know how the general procedure of learning } \\
\text { implementation in the class. }\end{array}$ & 4.17 & Good & 3.80 & Good \\
3 & $\begin{array}{l}\text { I know how to set the class. } \\
\text { I was able to adjust my teaching style to } \\
\text { students who had different characters. }\end{array}$ & 4.17 & Good & 3.90 & Good \\
5 & $\begin{array}{l}\text { I can customize My learning process based } \\
\text { on what students already understand and do }\end{array}$ & 4.10 & Good & 3.87 & Good \\
$\begin{array}{l}\text { not understand. } \\
\text { I can use a variety of methods, strategies, } \\
\text { techniques, approaches, models, and media } \\
\text { learning in the class. }\end{array}$ & & Good & 3.00 & Good \\
\hline $\begin{array}{l}\text { I can find out the misunderstanding } \\
\text { (misconceptions) of students against a } \\
\text { concept or material. }\end{array}$ & & Good & 3.00 & Good \\
\hline $\begin{array}{l}\text { I can assess student learning using various } \\
\text { types of assessments. }\end{array}$ & 4.00 & Good & 3.83 & Good \\
\hline
\end{tabular}

Table 3. Shows data about the average value of preservice teachers of Civic education in group lecture programs A and group B. Total average value of PK preservice teachers Civic education in group lecture program $A$ is higher than in the group lecture program B. On all items statements on group A or B get A good predicate. Knowledge of general procedures of implementation of learning in class and arrangement of class management got a good predicate on group $A$ with a value of 4.17 , the value is higher than group tilapia $B$ in the same grain. However, there is a considerable difference in value between group $A$ and group $B$ on the knowledge related to the general procedure of learning implementation in a class which both have a value difference of more than 0.30 . In contrast, in the knowledge related to the general procedure of group learning implementation $B$ has a value of 3.80 , it is the lowest value on group $B$. There are 3 values in common preservice teachers group A of 4.00 on the content: ability to In using a variety of methods, strategies, techniques, approaches, models, and media learning in the classroom; Ability to know the misunderstanding (misconceptions) of a student against a draft or material; and the ability to assess student learning using different types of assessments. On the same content in group $B$ also experienced equal value of 3.83. In other statement items, there is no significant difference in value.

The next ability of Pedagogical Content Knowledge (PCK) capabilities, the result of the PCK preservice teacher's ability to group class $A$ with group $B$ in the following table.

Table 4 Ability Pedagogical Content Knowledge (PCK)

\begin{tabular}{clcccc}
\hline No. & Statement & A & Description & B & Description \\
\hline 1 & I can make RPP in the subjects Civic education. & .4 .27 & Good & 3.90 & Good \\
2 & $\begin{array}{l}\text { I can choose various methods, strategies, } \\
\text { techniques, approaches, models, and media }\end{array}$ & & Good & 4.00 & Good \\
$\begin{array}{l}\text { according to the material Civic education. } \\
\text { I can make Civic education material that is difficult } \\
\text { to understand to be easy to understand by } \\
\text { students. }\end{array}$ & & & & & \\
\end{tabular}




\begin{tabular}{cccccc}
\hline No. & \multicolumn{1}{c}{ Statement } & A & Description & B & Description \\
\hline 4 & $\begin{array}{l}\text { I can make linkages between Civic education } \\
\text { subject matter with other materials. }\end{array}$ & 3.93 & Good & 3.67 & Good \\
\hline $\begin{array}{l}\text { I can make linkages between Civic education } \\
\text { subject matter with other subject matter. }\end{array}$ & 3.93 & Good & 3.63 & Good \\
\hline 6 & $\begin{array}{l}\text { I can use various learning resources to teach the } \\
\text { material Civic education. }\end{array}$ & 4.17 & Good & 4.00 & Good \\
\hline 7 & $\begin{array}{l}\text { I can make myself a grid and test questions on the } \\
\text { subjects Civic education. }\end{array}$ & 4.20 & Good & 3.73 & Good \\
\hline Total & $\mathbf{4 . 0 9}$ & Good & $\mathbf{3 . 8 1}$ & Good \\
\hline
\end{tabular}

Table 4. Show data on the average value of PCK preservice teachers in Civic education on group lecture program $A$ and group $B$. Total average value of PCK preservice teachers in $A$ group coursework $A$ higher than group $B$. On all items statements on group $A$ or $B$ get $A$ good predicate. Knowledge of the creation of RPP on the subject of Civic education got a good predicate on the group $A$ with a value of 4.27 then the value is 0.37 higher than the group tilapia $B$ in the same grain. In contrast, the knowledge about making the linkage between Civic education material with other subjects on group B with the value of 3.63 then the value is the lowest value of the group $B$. However, there are sufficient differences in the value of Between group $A$ and group $B$ on the ability to create lattice and test problems on Civic education subjects that have a difference in value of more than 0.40 . In other statement items, there is no significant difference in value.

Next ability of ability. Technological. Content. Knowledge. (TCK), result of TCK ability of preservice teachers Civic education group class A with group B in the following table.

Table 5 capabilities of Technological Content Knowledge (TCK)

\begin{tabular}{|c|c|c|c|c|c|}
\hline No. & Statement & A & Description & B & Description \\
\hline 1 & $\begin{array}{l}\text { I know the various technologies that I can } \\
\text { use to study the educational material of } \\
\text { Pancasila and Citizenship (Civic education). }\end{array}$ & .3 .93 & Good & 3.87 & Good \\
\hline 2 & $\begin{array}{l}\text { I can use certain computer/laptop application } \\
\text { to facilitate I understand the material Civic } \\
\text { education. }\end{array}$ & 4.23 & Good & 4.10 & Good \\
\hline 3 & $\begin{array}{l}\text { I can use the computer/laptop well to } \\
\text { develop (compose paper and create } \\
\text { presentation slides) material Civic education. }\end{array}$ & 4.30 & Good & 4.17 & Good \\
\hline 4 & $\begin{array}{l}\text { I use the Internet technology as a source of } \\
\text { learning to find the material Civic education. } \\
4\end{array}$ & 4.37 & Good & 4.27 & Good \\
\hline 5 & $\begin{array}{l}\text { I use communication technologies such as } \\
\text { Whatsapp, BBM, Line, and others to discuss } \\
\text { Civic education with peers. }\end{array}$ & 4.30 & Good & 4.23 & Good \\
\hline 6 & $\begin{array}{l}\text { I use social media such as Facebook, } \\
\text { Instagram, Twitter, blog, and others to post } \\
\text { and express my understanding of the } \\
\text { material Civic education. }\end{array}$ & 3.90 & Good & 3.60 & Good \\
\hline 7 & $\begin{array}{l}\text { I can use social media like. Twitter. Linkedin, } \\
\text { Facebook,. and others to connect with the } \\
\text { leaders of Indonesian scientists in Indonesia. }\end{array}$ & 3.63 & Good & 3.20 & Enough \\
\hline & Total & 4.10 & Good & 3.92 & Good \\
\hline
\end{tabular}

Table 5. Shows data on the average value of TCK's preservice teachers in Civic education on group coursework group $A$ and B. Total average value of TCK preservice teachers in group coursework A slightly higher than in group lecture programs B. All statement items on group $A$ is given a good predicate, while there is a statement on Group $B$ that got the predicate enough. Knowledge of the use of Internet technology as a source of learning to find the material Civic education got a good predicate on group $A$ with a value of 
4.37 then the value is higher than 0.10 group tilapia B in the same grain. In contrast, related to the use of social media such as Twitter, Linkedin, Facebook, and so on to connect with the science leaders Civic education in Indonesia on group B only get the value of 3.23 with enough predicate, this value is a value Lowest on group $B$. In other statement items, there is no significant difference in value and no equal value.

The next ability in the ability of Technological Pedagogical Knowledge (TPK), the result of the ability to TPK preservice teachers group class $A$ with group $B$ in the following table.

Table 6 Ability Pedagogical Knowledge of Technological (TPK)

\begin{tabular}{|c|c|c|c|c|c|}
\hline No. & Statement & A & Description & B & Description \\
\hline 1 & $\begin{array}{l}\text { I can choose a technology that can improve } \\
\text { the learning strategy in the class. }\end{array}$ & .4 .03 & Good & 3.97 & Good \\
\hline 2 & $\begin{array}{l}\text { I think how to use technology can affect the } \\
\text { learning strategy in the class. }\end{array}$ & 4.07 & Good & 3.83 & Good \\
\hline 3 & $\begin{array}{l}\text { I was able to choose a technology that could } \\
\text { enhance the attractiveness of students } \\
\text { during the learning process. }\end{array}$ & 4.07 & Good & 3.97 & Good \\
\hline 4 & $\begin{array}{l}\text { I think critically about how to use technology } \\
\text { in learning in the classroom. }\end{array}$ & 3.90 & Good & 3.83 & Good \\
\hline 5 & $\begin{array}{l}\text { I was able to adapt myself to use technology } \\
\text { on learning in class. }\end{array}$ & 4.07 & Good & 3.90 & Good \\
\hline 6 & $\begin{array}{l}\text { I can choose the technology that can be } \\
\text { used to improve the learning outcomes in the } \\
\text { class. }\end{array}$ & 4.03 & Good & 3.90 & Good \\
\hline 7 & $\begin{array}{l}\text { I can help other teachers to use the } \\
\text { technology in learning in the classroom. }\end{array}$ & 3.97 & Good & 3.77 & Good \\
\hline & Total & 4.02 & Good & 3.88 & Good \\
\hline
\end{tabular}

Table 6. Shows data on the average value of TPK preservice teachers in Civic education on group lecture group A and $B$. The average value of TPK preservice teachers in group coursework $A$ slightly higher than in group lecture programs $B$. On all items statements both on group $A$ and $B$ get $A$ good predicate. Knowledge of how technology is used can affect classroom learning strategies; Choose technologies that can improve students ' appeal during the learning process; and the ability to adapt to use technology on learning in the classroom, got a good predicate on the group $A$ with the same value of 4.07 then the value is higher than the group value $B$ in the same item. In contrast, knowledge about helping other teachers to use technology in learning in the classroom only gets a good predicate on the group B with a value of 3.77 then it is the lowest value on group $B$. Nevertheless, There is a significant difference in the value between group $A$ and group $B$ on the ability to think deeper about how technology can affect learning strategies that both have a difference in the value of 0.24 . In other statement items, there is no significant difference in value and no equal value.

The next ability of TPACK capability, the result of TPACK capability for preservice teachers Civic education group class $A$ with group $B$ in the following table.

Table 7 TPACK Capabilities

\begin{tabular}{cccccc}
\hline No. & \multicolumn{1}{c}{ Statement } & A & Description & B & Description \\
\hline 1 & $\begin{array}{l}\text { I can use the appropriate technology in the } \\
\text { appropriate learning strategy to convey the } \\
\text { material properly }\end{array}$ & 4.00 & Good & 3.83 & Good \\
$2 \quad \begin{array}{l}\text { I was able to choose the technology } \\
\text { appropriately to add students ' understanding } \\
\text { of the Civic education material taught using a } \\
\text { specific learning strategy. }\end{array}$ & & Good & 3.07 & Good \\
I can choose the right technology to assess & 3.90 & Good & 3.90 & Good \\
\hline
\end{tabular}




\begin{tabular}{|c|c|c|c|c|c|}
\hline No. & Statement & A & Description & B & Description \\
\hline & $\begin{array}{l}\text { the outcome of learning by using a specific } \\
\text { learning strategy. }\end{array}$ & & & & \\
\hline 4 & $\begin{array}{l}\text { I can carry out good learning by combining } \\
\text { the proper use of technology and choosing } \\
\text { the right learning strategy on the subject of } \\
\text { Civic education. }\end{array}$ & 3.93 & Good & 3.83 & Good \\
\hline 5 & $\begin{array}{l}\text { I can help other teachers to use the right } \\
\text { technology on the learning strategy in } \\
\text { accordance with certain materials in the } \\
\text { learning }\end{array}$ & 3.87 & Good & 3.70 & Good \\
\hline & Total & 3.95 & Good & 3.81 & Good \\
\hline
\end{tabular}

Table 7 shows data on the average value of TPACK for teachers of Civic education in group lecture group A and group B. The average value of TPACK's preservice teachers in the group coursework $A$ is higher than the group value $B$. On all items statements both on group $A$ and $B$, get $A$ good predicate. The precise knowledge of technology selection to add to students understanding of the Civic education material taught using a particular learning strategy gets a good predicate at group A with a value of 4.07 , the value is 0.27 higher than Group value B on the same item. In contrast, knowledge about helping other teachers to use the appropriate technology in the learning strategy according to the specific material in the study on the group $B$ with the value of 3.70 then the value is the lowest value of the group $B$. However, there are similarities to the group $A$ and $B$ values about choosing the right technology to perform student learning outcomes assessments taught using a specific learning strategy in the classroom with a value of 3.90. In other statement items, there is no significant difference in value.

TPACK capability of Civic education preservice teachers have the distinction between group students $A$ with group students $B$. If the TPACK component of preservice teachers of group Civic education $A$ higher value than preservice Civic education group teachers $B$, it can be seen from various TPACK capabilities such as TK, CK, PK, PCK, TCK, TPK, and TPACK. The explanation of these components will be shown in the discussion of this study.

The ability of group Technology Knowledge (TK) B is the lowest among other TPACK components, for example in the knowledge of various computer hardware or laptops (functions of: Motherboard, RAM); Knowledge of various types of computer technology or laptops of different brands; Knowledge of image processing programs (Adobe Photoshop); Have the ability to tamper with technology devices to find out more; Knowledge of computer software or laptops (example: Windows, Media Player). The ability of technology is very important to have a teacher, especially in the current era in the world of education also use various technological sophistication. Teachers in the era of Revolution 4.0 industry must have capability in the use of technology as a media learning, because in this age teachers must face students who are accustomed to use technology in his life so that teachers who do not understand technology is very difficult in teaching (Nursyifa, 2019).

Mastery of technology is needed today to process a variety of information, communication processes, and as a way to solve problems in life (Judith Harris, Mishra, \& Koehler, 2009). The ability of preservice teachers in using technology in learning is very important mastered by preservice teachers both technology in the form of hardware and software, in accordance with the research conducted Dhawati \& Hariyatmi (2006) preservice teachers Technological Knowledge (TK) ability It is very important to possess both technological capabilities in the form of hardware and software so that the learning in running effectively, efficiently, and innovative.

In research instruments, researchers analyze how much the knowledge of preservice teachers both group A and group B related to their knowledge of technology, one of the causes of their lack of knowledge related to good technology preservice teachers group $A$ or group student $B$ teachers have never participated in a course or training related to technology or IT. Therefore, knowledge about technology needs to be improved again and can also operate well as a tool in learning, so that with the technological capabilities of good 
preservice teachers will produce innovations in the media Learning, this in line with Muslim research, et al (2012) TPACK can function in the development of innovative learning models.

Content Knowledge (CK) capability must be developed by preservice teachers related to his knowledge in the field of Civic education, so that with knowledge of the content of Civic education capable to be taught to students well. Knowledge of Civic education content can be a knowledge of various concepts, ideas, theories, empirical evidence, and various new approaches to the science of Civic education (Rahayu, 2017). Based on table 2 knowledge of $\mathrm{CK}$ or knowledge of material content related to the subjects of Civic education group teachers A higher than group B especially in the knowledge of science figures in the field of Civic education in Indonesia and development Latest book on Civic education material. On knowledge of the content of group Civic education A proved to be higher than group B, but on the other hand when compared with other TPACK content this knowledge is very low on group A.

Becoming an evaluation that preservice teachers should develop their knowledge well, especially at this time various information in the framework of the development of science happens very rapidly and preservice teachers can develop a variety of content Civic education easily, for example: With the use of the Internet can add new information about the development of Civic education content in the world and Indonesia; preservice teachers can get a variety of latest information related to the scientific knowledge of social media (such as Instagram, Facebook, Twitter) in which there is a variety of information seminar Civic education; Civic education content development can also be obtained various media such as television, newspaper, magazines, and so on; The existence of technology today has indeed shifted the existence of books, preservice teachers can use e-books and various journal references for the research results to increase knowledge about Civic education; Various important issues and problems updated related to Civic education can be found in various information media so that preservice teachers must enrich the various sources of literacy in the science development of Civic education, therefore the existence of TPACK can be Add various sources of literacy in learning (Irmita \& Atun, 2017). The existence of technology in adding literacy to study various relevant issues related to Civic education content becomes an important step in developing critical thinking skills according to the demands of skills in the 21st century, similar to Research conducted by Mairisiska, Sutrisno, \& Asrial (2014) TPACK's ability to develop learners ' skills to think critically.

Ability Pedagogical Knowledge (PK) preservice teachers group Civic education $A$ higher than the preservice group teacher B. Knowledge of pedagogy is very important owned by preservice educators, related to the knowledge pedagogy is a knowledge preservice teachers about the practice Teaching that starts from planning in teaching, strategies or methods used in teaching, class management strategies, to the assessment in the classroom. Pedagogy knowledge obtained by preservice teachers during the education in college, so before the preservice teachers do field experience practice in the 7th semester, the pedagogic ability must be well-owned even a prerequisite To follow field experience practices. The knowledge of pedagogy is one of the important instruments in TPACK, the pedagogic ability that the teachers possess needs to be improved because of the ability to prove the mastery of teaching by preservice teachers (Slamet, 2014). If viewed in table 3 It is clear that the pedagogic ability of group teacher B need to be improved especially on the ability associated with the general procedure of implementation of learning in the classroom; Ability to use various strategies, methods, models, techniques, approaches, learning media in the classroom; Ability to know the misunderstanding (misconceptions) of a student against a draft or material; and the ability to assess student learning using different types of assessments. Lack of experience in preservice teachers in teaching become a major factor in the pedagogic ability of preservice teachers, this is similar to the research of Harris, et al (2011 preservice teachers who lack the teaching experience have limited knowledge in student learning So it is difficult to predict learning difficulties and to know students ' misunderstandings about learning. If analyzed based on the teaching experience of group teachers $A$ and $B$ averages have never taught, therefore field experience practices become the momentum of preservice teachers in applying the various knowledge he has during the 
course of studying in the Actual teaching. Therefore, the knowledge of pedagogy needs to be improved first for preservice teachers before they act directly as a real teacher.

The next ability of Pedagogical Content Knowledge (PCK) skills, pedagogic knowledge of preservice teachers related to the content of Civic education material, this knowledge is very important for preservice teachers so that with this knowledge preservice teachers can know So that the content of the subject matter taught by the teacher can be understood by the students, in line with the research of Koehler, Mishra, \& Cain (2017) PCK associated with the knowledge that teachers have to interpret the content of the lesson so that the learning Effective running. Many other TPACK research results show teachers who have the ability of PCK can integrate various aspects of material content knowledge with the pedagogic ability (Rahayu, 2017). PCK is one of the most important items in TPACK that help preservice teachers improve their learners ' understanding of learning content (Apriliani, 2017). Based on table 4 results of the ability of Pedagogical Content Knowledge (PCK) preservice teachers can be analyzed Civic education that proved to be group class teacher $\mathrm{B}$ is lower than group A especially the ability in making material linkage one with In the subject of Civic education; Ability in making the linkage material with other subjects such as IPS, sociology, economics, history, and so on; Ability to make Civic education material difficult to understand to be easy for students to understand; and the ability to create their own grid and test problems on the subject of Civic education.

Knowledge of Technological Content Knowledge (TCK) is owned by the teachers, knowledge of technological content related to the teacher's understanding of the utilization of technology associated with the content of Civic education material. Based on the results of the ability Technological Content Knowledge (TCK) preservice teachers Civic education group class $A$ has a higher value than group $B$ especially about the use of social media such as Instagram, Facebook, Blog, Twitter, and others to post and express understanding of Civic education material; Knowledge of various technologies that can be used to study the material education of Pancasila and Citizenship (Civic education); and the lowest value of social media usage items such as Linkedin, Twitter, Facebook, and others to connect with Civic education scientists in Indonesia. TCK disadvantages of preservice teachers because nowadays with the ease of technology preservice teachers Civic education can access literacy related to the content or the reference lecture, but unfortunately, the facility precisely makes preservice teachers become lazy to learn Because it only copies-pasting from other people's work. In accordance with the research Miskahuddin (2017) that the ease of Internet technology makes students less motivated to learn. Moreover, the use of social media is not for the purpose of adding science literacy about Civic education especially to join social media with the leaders of Civic education, social media use only for entertainment purposes is not an academic interest. Therefore, the preservice teachers can develop technology for academic importance especially in improving knowledge about Civic education.

Next ability of ability. Technological Pedagogical Knowledge (TPK), TPK is the knowledge of preservice teachers related to technology in education. Results of the ability of Technological Pedagogical Knowledge (TPK) preservice teachers group class A higher than group $B$ can be seen in table 6 , various technological capabilities found in group teachers $B$ need to be further improved especially in Ability to be able to think about how technology utilization affects learning strategies that can be used in the classroom; Critical thinking skills for the use of technology in classroom learning; And can help other teachers to use the technology. In TPK teachers are required to be creative and critical in using technology in teaching, similar to a variety of TPACK research that TPACK can develop creative thinking skills to utilize technology in teaching School (Munif, Budi, \& Nur, 2019); TPACK can develop critical thinking skills towards teaching in schools (Mairisiska, Sutrisno, \& Asrial, 2014).

The final ability of Technological Pedagogical Content Knowledge (TPACK). According to Koehler and Mishra (2009) that TPACK is basically formed from three main components, namely content of subject matter, pedagogic, and technology. These three components relate to each other so that teaching can run effectively according to the objectives. TPACK is a basic knowledge that must be owned by preservice teachers, because with the existence of TPACK can assist in teaching and learning so that the 
knowledge of preservice teachers can be sharpened about what technology is appropriate to use in teaching, pedagogy knowledge of what is right in the teaching, as well as the knowledge of the various material content in teaching. Result of TPACK capability preservice teacher Civic education group class A higher than group B can be seen in table 7. A low B group TPACK capability that needs to be further improved especially in the ability to help other teachers to use the appropriate technologies on learning strategies that fit the specific material in classroom learning; Students ' understanding is increased because teachers use the right technology to Civic education materials taught using specific learning strategies in the classroom; Able to use appropriate technology in the appropriate learning strategy to convey the material of Civic education well in the classroom; and the ability to perform good learning by combining the proper use of technology and good strategies in accordance with Civic education material in the classroom.

Based on the results of the analysis of various components of TPACK, the results of the study is the difference in the ability of TPACK preservice teachers Civic education in the study program Civic education, Faculty of Teacher Training and Education Pamulang University on group program A with group $B$, from all the components of the average TPACK Mastery of TPACK ability of preservice teachers A group Civic education A superior than group $B$. Therefore, this research provides the findings that the ability of TPACK preservice teachers of group Civic education B who cannot be influenced by various cause factors such as can Analyzed from the characteristics of group lecture B on Monday to Friday but the lecture time is done at night between 18.20 WIB to 21.40 WIB in short time lecture because it is done at night to be a factor is important to the lack of ability of the preservice teachers, when compared with the group lecture $A$ that time the lecture at 07.10 WIB to $15.00 \mathrm{WIB}$. Group teachers B are mostly workers who in the morning they work while in the evening they lecture so that when the lecture takes place in the evening they are less focused on learning, ultimately the motivation to learn students The students who are under group student $A$.

Based on the findings, it can be used as an evaluation of higher education to pay attention to the choice of lecture time, so that the lecture can walk conducive and good. The success of TPACK is also supported by complete facilities and infrastructures from universities and supported by teachers or lecturers who are competent and qualified especially have the ability of TPACK so that with the teaching staff Professionals can produce future teachers. TPACK ability of preservice teachers Civic education needs to be improved as an effort to prepare future preservice teachers especially in the field of technology. Facing the change of era of the Industrial revolution 4.0 preservice teachers are expected to adapt to the demands of the times and can become professional teachers.

Improved literacy in the use of technology needs to be improved on higher education institutions that print preservice teachers. Various ways preservice teachers can do in the development of TPACK, including; 1) preservice teacher can follow a focus lecture on education technology; 2) the preservice tacher has the ability to use the learning strategy in the lecture; and 3) preservice teacher can use the learning strategy in the overall teacher education program (Mouza, 2016:176). Before students conduct teaching practice at school, they are already equipped with the ability of TPACK by integrating various capabilities in designing learning, developing technology-based learning, can utilize technology in each learning process, manage learning well, and evaluate the use of technology in learning. In addition, the development of TPACK is also done by observing various content from the subject matter, learning strategy, learning objectives, and various pedagogic skills that have preservice teacher.

TPACK capability cannot be owned preservice teacher if not supported by qualified lecturers to develop technology in learning so that can be imitated by preservice teacher. In addition, the learning facilities in college provide TPACK technology devices are also needed so that preservice teachers can be skilled in the use of technology in learning. Therefore, it is necessary to role all parties to develop TPACK skills in college, so that can print future teachers who are ready to face the era of revolution 4.0 industry, become professionals educators who can compete at the local, national, or global level. 


\section{Conclusion and Suggestion}

The capability of TPACK has a very important role in enhancing the ability of the preservice teachers in the era of Revolution 4.0 industries, it is demanded that preservice teachers can have the knowledge and can operationalize various technologies in education. TPACK capability of preservice teachers Civic education still needs to be developed consisting of TK, CK, PK, PCK, TCK, TPK, and TPACK capability. The findings of this research demonstrate the ability of TPACK preservice teachers in the group program $A$ is superior to the group $B$, this is due to the lack of motivation of students in lectures due to the time of lecture in the night which is less conducive and Students with predominantly Bworkers. Therefore, it needs the role of all parties so that the problem can be solved properly so that the college can print future teachers who are superior can compete in a local, national, or global level.

Based on the findings, researchers advise higher education providers to evaluate the choice of time for preservice teachers, facilitate a variety of learning technologies for preservice teachers in order to develop the ability TPACK, and supported by professional teachers who can give birth to qualified future teachers. Advice to further researchers to be able to improve this research by reviewing more in depth related to the instruments performed in subsequent studies.

\section{References}

Agustina, P., Yusron, F. N., \& Muyassarah, F. (2018). Pedagogical content knowledge (PCK) mahasiswa calon guru biologi FKIP UMS pada matakuliah microteaching tahun akademik 2015/2016. In The 7th University Research Colloqium 2018 (pp. 101-108). Surakarta, Central Java, Indonesia: STIKES PKU Muhammadiyah Surakarta.

Apriliani, D. (2017). Pengembangan Perangkat Pembelajaran TPACK pada Pelajaran Basis Data Untuk Meningkatkan Pemahaman Konsep. Universitas Pendidikan Indonesia.

Arbiyanto, U. F., Widiyanti, \& Nurhadi, D. (2018). Kesiapan TPACK Calon Guru Bidang Teknik di Universitas Negeri Malang. Jurnal Teknik Mesin dan Pembelajaran, 1(2), 19.

Baser,D. Kopcha,T.J \& Ozden, M.Y.(2015). Developing TPACK Assessment for Preservice Teachers Learning to Teach English. Computer Assisted Language Learning, 1-16. https://doi.org 10.1080/ 09588221.2015. 1047456

Bilici, S.C, Guzey,S.S, dan Yamak,H. (2016). Assessing Preservice Science Teachers TPACK Through Observation \& Lesson Plan. Research in Science and Technological Education, 34(2), 237-251. https://doi.org /10. 1080/ 02635143. 2016. 1144050

Canbazoglu Bilici, S., Guzey, S. S., \& Yamak, H. (2016). Assessing preservice science teachers' technological pedagogical content knowledge (TPACK) through observations and lesson plans. Research in Science \& Technological Education, 34(2). https://doi.org/10.1080/02635143.2016.1144050

Cuhadar, C. (2018). Investigation Preservice Teachers Level of Readiness Technology Integration in Education. Contemporary Educational Technology, 9(1), 61-75. Diambil dari https: //files. eric.ed. gov/fulltext/EJ1166420.pdf

Dhawati, D.A.A. (2017). Kemampuan TPACK Calon Guru Biologi dalam Menyusun RPP Kurikulum 2013. Diambil dari http://eprints.ums.ac.id/53501/

Dhawati, D.A.A., \& Hariyatmi. (2006). Kemampuan TK Calon Guru Biologi FKIP UMS Seminar Nasional Pendidikan Biologi dan Saintek (hal. 649-654). Surakarta: Universitas Muhammadiyah Surakarta.

Direktorat Jenderal Pembelajaran dan Mahasiswa. (2018). Pedoman Penyelenggaraan Pendidikan Profesi Guru. Jakarta: Dirjen Belmawa.

Drew, S. V. (2013). Preparing Students For 21 Century Literacy. Journal of Adolescent and Adult Literacy, 56 (4), 321-330. https: //doi.org/ doi :10.1002 /JAAL. 00145

Fatonah, .L. (2017). Kemampuan PCK calon guru biologi dalam menyusun RPP kurikulum 2013 tahun akademik 2016/2017. Universitas Muhammadiyah.Surakarta. 
Guzman, A. dan N. (2009). Teaching competencies technology integration in classroom. Journal of Computer Assisted Learning, 25, 453-469. https://doi.org /10.1111/j. 13652729. 2009. 00322.x

Harris, Judi, Grandgenett, N., \& Hofer, M. (2011). Using Structured Interviews to Assess Experienced Teacher TPACK. In Society for Information Technology \& Teacher Education International Conference (hal. 4696-4703). Texas. Diambil dari https://www.learntechlib.org/p/40351/

Harris, Judith, Mishra, P., \& Koehler, M. (2009). Teacher Technological Pedagogical Content Knowledge \& Learning Activity Types: Curriculum based Technology Integration Reframed. Journal of Research on Technology Education, 41(4), 393-416. Diambil dari www.iste.org

Irmita, L.U. dan Atun, S. (2017). Pengembangan Pembelajaran Pendekatan TPACK untuk Meningkatkan Literasi. Tadris Kimiya, 1(2), 84-90.

Jang, S., \& Tsai, M. (2012). Computers and Education Exploring TPACK of Taiwanese elementary mathematics and science teachers with respect to use of interactive whiteboards. Computers \& Education, 59(2), 327-338. https://doi.org /10. 1016/j. compedu. 2012. 02.003

Kereluik, K. Mishra, P. Fahnoe, C. \& Terry, L. (2013). What Knowledge Is of Most Worth: Teacher Knowledge for 21 Century Learning. Journal of Digital Learning in Teacher Education, 29(4), 127-140. https:// doi.org/ 800. 336. 5191

Koehler, M. J. \& Mishra, P. (2005). Teachers Learning Technology by Design. Journal of Computing in Teacher Education, 21(3), 94- 102. https://doi.org /10.1080 /10402454 .2005. 10784518

Koehler, M. J., \& Mishra, P. (2009). What Is Technological Pedagogical Content Knowledge Contemporary Issues in Technology and Teacher Education, 9(1), 60-70.

Koehler, M. J., Mishra, P., \& Cain, W. (2017). What Is TPACK? Journal of Education. 193(3). https://doi.org /https://doi.org /10.1177/ 002205741319300303

Listiawan, T., \& Baskoro, W. (2015). Analisis TCK Calon Guru Matematika Dalam Menggunakan Perangkat Lunak Geometri Dinamis. Seminar Nasional Matematika dan Pendidikan Matematika (hal. 827-834). Yogyakarta: Universitas Negeri Yogyakarta.

Maeng, J. L., Mulvey, B. K., Smetana, L. K., \&. Bell, R. L. (2013).nPreservice Teachers.TPACK : Using Technology to Support Inquiry Instruction. Journal of Science Education and Technology, 22(6), 838-857. https: //doi. org /10.1007/ s10956 -0139434-z

Mairisiska, T., Sutrisno, \& Asrial. (2014). Pengembangan Perangkat Pembelajaran TPACK pada Materi Sifat Koligatif Larutan untuk Meningkatkan Keterampilan Berpikir Kritis Siswa. Jurnal Edu Sains, 3(1), 28-37.

Mishra, P., \& Koehler, M. (2006). Technological Pedagogical Content Knowledge: A Framework for Teacher Knowledge. Teachers College Record, 108(6), 1017-1054.

Mishra, P., \& Koehler, M. J. (2008). Introducing Technological Pedagogical Content Knowledge. New York. Diambil dari http:/ /www. matt- koehler. com/publications/ Mishra Koehler AERA 2008.pdf

Miskahuddin. (2017). Pengaruh Internet Terhadap Penurunan Minat Belajar Mahasiswa. Jurnal Mudarrisuna, 7(2), 293-312. Diambil dari https: // jurnal. ar-raniry .ac.id/index. php/mudarrisuna /article/view/2366/1711

Mouza, C. (2016). Developing and accessing TPACK among preservice teachers. Handbook of technological pedagogical content knowledge (TPACK) for educators. Diambil dari https:// books. google. co.id

Muhson, A. (2010). Pengembangan Media Pembelajaran Berbasis Teknologi Informasi. Jurnal Pendidikan Akuntansi Indonesia, 8(2), 1-10. https://doi.org/10.21831/jpai.v8i2.949

Munif, A., Budi, S., \& Nur, A. (2019). Kemampuan Berpikir Kreatif ditinjau dari Adversity Quotient pada Pembelajaran TPACK. In Prosiding Seminar Nasional Matematika (Vol. 2, hal. 40-45). Semarang: Universitas Negeri Semarang. Diambil dari https:// journal. unnes. ac.id/sju/index. php/ prisma/ 
Muslim, Mursid, \& Yuniarto. (2012). Pengembangan Model Pembelajaran Inovatif Berbasis Kerangka Kerja TPACK Bagi Guru Kejuruan di SMK. Medan.

Nursyifa, A. (2019). Transformasi Pendidikan IImu Pengetahuan Sosial dalam Menghadapi Era Revolusi Industri 4.0. Jurnal Pendidikan Kewarganegaraan, 6(1), 51. https://doi.org/10.32493/jpkn.v6i1.y2019.p51-64

Rahayu, S. (2017). TPACK Integrasi ICT dalam Pembelajaran IPA Abad 21. In Prosiding Seminar Nasional Pendidikan IPA (hal. 1-14). Malang: Universitas Negeri Malang.

Raman,.A. (2014). TPACK Confidence of Pre-service Teachers in Universiti Utara Malaysia. Mediterranean Journal of Social Sciences, 5(22), 167-175. https://doi.org/10.5901/mjss. 2014. v5n22p167

Sahin, I. (2011). Development of Survey of Technological Pedagogical and Content Knowledge (TPACK). The Turkish Online Journal of Educational Technology, 10(1), 97-105. Diambil dari https: //eric.ed. gov/?id = EJ926558

Schmidt, D. A., Baran, E., Thompson, A. D., Mishra, P., Koehler, M. J., \& Shin, T. S. (2009). Journal of Research on Technology in Education Technological Pedagogical Content Knowledge (TPACK). Journal of Research on Technology in Education, 42(2), 123149. https:/ /doi. org/10. 1080/ 15391523. 2009. 10782544

Schwab, K. (2016). The Fourth Industrial Revolution. Switzerland: World Economic Forum.

Sholihah, M. (2016). Technological Pedagogical Content Knowledge dan Kemampuan Menyusun Perangkat Pembelajaran Calon Guru Fisika melalui Model Pembelajaran Post Pack. Program Pascasarjana Universitas Negeri Malang. Diambil dari http:/ /karya- ilmiah. um.ac. id/index. php/ disertasi /article

Sholihah, M., Yuliati, L., \& Wartono. (2016). Peran TPACK Terhadap Kemampuan Calon Guru Fisika dalam Pembelajaran Post Pack. Jurnal Pendidikan: Teori, Penelitian, dan Pengembangan, 1(2006), 144-153. Diambil dari http:// journal. um.ac.id/ index.php/ jptpp/ article/view /6115/2572

Slamet, T. I. (2014). Guru dan Digital Superhero: Gamifikasi Untuk Peningkatan Kompetensi TPACK Calon Guru. In Seminar Nasional Pendidikan (hal. 435-445). Malang: Universitas Negeri Malang.

Sukaesih, S., Ridlo, S., \& Saptono, S. (2017). Lembaran IImu Kependidikan Profil Kemampuan Pedagogical Content Knowledge (PCK) Calon Guru Biologi. Lembaran IImu Kependidikan, 46(September), 68-74. Diambil dari http:/ /journal. unnes.ac. id/nju/ index. php/ LIK. 